ADDIN, Volume 13, Number 1, February 2019

\title{
The Definition of Private and Public Space in Implementation of Qanun Jinayah in Aceh
}

\section{Faradilla Fadlia}

Universitas Syiah Kuala Banda Aceh, Indonesia

acehfaradilla_fadlia@unsyiah.ac.id

\section{Ismar Ramadani}

Universitas Almuslim Bireuen, Aceh, Indonesia ismar.ramadani1984@gmail.com

\begin{abstract}
This paper will discuss how the Qanun Jinayah differentiate the concept of private and public space in the implementation of sharia in Aceh. This paper will particularly discuss how private and public space being defined in the Qanun and how broad the scope of this Qanun is. This paper finds that there is no private space in Qanun Jinayah. There are only two conditions that listed in Qanun Jinayah, first, when at the work place, second evidence by the family card. A person who committed to criminal act (jarimah) in private and public space, he or she will be punished by Qanun Jinayah. Because of that Government in this case Wilyatul Hisbah and investigator has right to enter a person's private space if that person is suspected to jarimah crime. This paper sees that the authority has changed to violate.
\end{abstract}

Keywords: Private Space, Qanun Jinayah, Aceh, Syariah Law, Caning. 


\section{Abstrak}

DEFINISI RUANG PRIBADI DAN RUANG PUBLIK DALAM IMPLEMENTASI QANUN JINAYAH DI $A C E H$. Tulisan ini akan membahas bagaimana Qanun Jinayah melihat konsep ruang privat dan ruang publik dalam pelaksanaan hukum tersebut di Aceh. Bagaimana ruang privat dan ruang publik di definisikan dalam Qanun ini dan seberapa luas cakupan dari Qanun ini. Temuan dari tulisan ini, bahwa tidak ada ruang privat dalam Qanun Jinayah. Hanya ada dua kondisi yang tercantum dalam Qanun Pasal 12, Bab III Alasan Pembenaran dan Alasan Pemaaf. (1) Setiap orang yang melakukan pekerjaan di tempat kerja dan pada waktu kerja tidak dapat dituduh melakukan jarimah khalwat dengan sesama pekerja. (2) Setiap orang yang menjadi penghuni sebuah rumah yang dibuktikan dengan daftar keluarga. Selama seseorang melakukan pelanggaran jarimah, baik di ruang privat maupun ruang publik, maka dia akan dikenai hukuman melalui Qanun Jinayah. Atas dasar itu, maka Wilayatul Hisbah (Polisi Syari'ah) atau penyidik diberikan kewenangan untuk memasuki ruang privat seseorang apabila seseorang tersebut diduga melakukan pelanggaran jarimah. Tulisan ini melihat bahwa kewenangan tersebut berpeluang melanggar hak asasi manusia seseorang.

Kata Kunci: Ruang Pribadi, Qanun Jinayah, Aceh, Hukum Syariah, Hukum Cambuk.

\section{A. Introduction}

Public and private spaces are the part that have never been discussed in the implementation of sharia law in Aceh, especially in the Qanun Jinayah. Particularly related to interaction between women and men who are accused of criminal act (jarimab) in the form of khalwat (immoral behavior), ikhtilath (making out and kissing), zina (having sex without married), liwath (gay), musaqah (Lesbian). Qanun Jinayah only recognizes interaction between men and women that are regulated in the Article 12 Chapter III for justification and forgiveness reason. (1) Everyone who works in the work place during working hours cannot be accused of 
doing khalwat with a fellow worker. (2) Everyone who register as a family member and proved by the family card cannot be accused of khalwat with another family member. This means that only in these two conditions, if there unmarried man and woman in certain place both in public and private space can be accused of doing a criminal act (jarimah) or other form of jarimah.

So far, no research has been conducted in the theme of public and private space in the implementation of Qanun Jinayah, although the application of Qanun Jinayah was applied in private space of society. In this point, issue that has been raised by the international organization and activist is that Qanun Jinayah and application of caning have violated human right especially in punishment and categorisation of offence. One example is the of objection for the punishment Gay couple that comes from Dede Oetama. He is an activist from Gaya Nusatara, an organisation advocating for Lesbian, Gay, Bisexual and Transgender (LGBT) right. Dede mentioned that government has done criminal act for arrested people who were having sex with consent. Another argument came from deputy director of human rights watch, he said that imprisoned a gay couple shows that Qanun Jinayab is a law that oppressing and discriminating LGBT people. ${ }^{1}$ However, the caning punishment is still done by the department of sharia law or Wilyatul Hisbah (WH) in Aceh.

Caning punishment is applied in various forms of criminal act (jarimah), according to the data from the Criminal Justice Reform (ICRJ) in 2016, the sharia court has decided 301 jinayah cases from January to November 2016. Throughout 2016, the numbers of 339 convicts were executed caning punishment in Aceh. 37 of the convicts are women while the majority of the convicts accused because of jarimah such as khalwat, ikhtilat, prevent, and zina. ${ }^{2}$

1 "Pertama di Aceh, Pasangan Gay Dihukum 85 Kali Cambuk", BBC (May 17, 2017), http://www.bbc.com/indonesia/indonesia-39944910, accesed March 1, 2017.

2 "Pemerintah Diminta Evaluasi Hukum Cambuk di Aceh", CNN (February 5, 2017), http://www.cnnindonesia.com/nasional/20170205144456-12-191415/ pemerintah-diminta-evaluasi-hukuman-cambuk-di-aceh, accessed October 1, 2017. 
Apart from all the issues around the controversies of Qanun Jinayah, this paper-focuses on the private and public space issue. Not on the form of violation-rather on how the government and the society enter a person's private sphere by the reason of criminal act (jarimah) in private space. Therefore this paper poses a question how does the Qanun Jinayah define Private space and public space? And The hypothesis of this paper is there is no private space in violation of criminal act (jarimab) in Qanun Jinayah of Aceh.

This paper uses the concepts of politic and space, politic and place, and order versus freedom.

\section{B. Discussion}

\section{Politic and Space}

Space can be interpreted as a control of territory, including the ownership of the objects within specific area or hierarchy. For example, a student who will have a party will not choose library to hold the occasion but he will choose a party room. Another example when a student come to the classroom they will immediately sit in the student chair and they will not sit in the lecturer chair because it will violate the power relation in the classroom setting. It explains how the society behaves and act according to geographic imagination under the sub-conscious. Spatial arrangement in society reflects power relationships. When a student come to the classroom and goes directly to the lecturer's desk the action defined as an attack on the lecturer's personal space and the action is related to opposition to the lecturer's power. The action of the student is defined as a strike to the status quo of lectures power and distracting the spatial arrangements in the classroom. ${ }^{3}$

Another example of the power and space relations we can see in the influence of the Europe to the Africa countries. In the $19^{\text {th }}$ century African as a colony under the power of Europe. Europe as an outsider who has power at that time claimed that the territory on

3 Colin Flint, Introduction to Geopolitics (Oxon: Routledge, 2006), 2-3. 
the mainland of Africa was under the power of Europe countries. Therefore, European was allowed to subdue the native African for economic gain and competed with other European nation to take control of African countries. After the imperialism era has ended, the African countries formed an independent country. Because of that, a new spatial arrangement was produced that based on gender, class and race. Space is a product from two-power relation. The first one is the ability of European nation to dominated African countries. The second power is the struggle between the European nations to control the colony of African countries. ${ }^{4}$

Furthermore, Friendrich Ratzle and Rudolf Kjellen in their book "laws of the spatial growth of states" stated that the state is a dynamic entity that grows with greater power and the driving force is a culture. The more powerful and advance a country, the more it has the right to expand its territory or control over another country. The justification of that action is because of the advanced country will use the land wisely. That knowledge has become a justification for Europe countries that have been labeled as superiors to expand their territory to Africa countries, which was perceived as inferior culture. $^{5}$

In this paper, politic and space talks about defining the space of geographical imagination under sub-conciseness of the people. Government (WH) and society have the power and act according the regulation in sharia territory. The state through its power regulates how people acts within the scope of particular space with could be different in another space. In other words, politic and space are internalization behaviors as a person entering the scope of space of imagination. Actually, internalization should be follow with conciseness of the usefulness of the action in that space and a wisdom from the decision making to ensure that no one is harmed by the implementation of a policy within a space. In this paper is Qanun Jinayah.

4 Flint, 2-3.

5 Martin Jones, Rhys Jones, and Michael Woods, An Introduction to Political Geography: Space, Place, and Politics (London: Routledge, 2004), 4-5. 


\section{Politic and Place}

Related to politics and place, Massey emphasized that the function of place is dynamic. Moreover, Massey stated that place is the network of social relations that have been formed overtime. Than it have been interacting with one and another, have been destroyed, repaired and renewed. Some of the relation will be there, while other will be expand to other place. Place bond the society with broader relationship and proceed with the involvement of other place. Furthermore, Massey reveals that place has two important functions. First, place is a result of the human activity and are socially constructed. Therefore, the function, characteristic and institution that founded in that place is rooted to the activity of the people in that area. Second, place develop dynamically from time to time. What people do in one place, what people wants and what people think change overtime that can be translate into the project that been create and renew. ${ }^{6}$

This paper see that the implementation of Qanun Jinayah as form of government effort to restore aceh for the islamic value that have been fought in the Aceh Government law (UUPA) as a mandate of the MoU Helsinki. Based on that MoU, government claims that shariah law is aspiration of Acehness, based on that government implemented Qanun Jinayah. Therefore, Aceh is the only province in Indonesia that has speciality in the implementation of criminal law (jarimah).

\section{Conceptual Framework in Analyzing Government Policy}

To analyze government policy in implementation of Qanun Jinayah, there are two concepts that will be used.

\section{a. Freedom}

One of the concepts that become a background for policies that adopted by the government is freedom for religion, freedom for voice opinion, and freedom for worship. It is the freedom to

6 Flint, Introduction to Geopolitics, 3-6. 
do what society wants. The other concepts is freedom from fear, freedom from oppression and exploitation. Government play a role to ensure that everyone has freedom to all activities that people wants to do. in other hands, government should ensure that individual freedom does not oppress and exploit other people. ${ }^{7}$

\section{b. Order}

The main functions of the government is to protect the people, property right and and ensure social order, likes regulating the behavior of society in social relation. To ensure social order government makes rule that bond the community regarding the acceptance traditional behavior. For example, student uniform, how a student behaves toward his teacher, about a legitimate married such as same-sex married, smoking in public area, what allows and not publish by media, pornography, and etc. the question that have raised to what extend government control society behavior in order to ensure social order. Government have right to produce policy because government have police power. ${ }^{8}$

\section{c. Government Dilemma: Order versus Freedom}

There will be always a question which should come first, are government should prioritize the social order or the freedom of individual? How much the individual freedom should been given to the government? The original purpose of government is to protect people and property right from crime. When Eastern Europe was under the communist, people fear were very difference with fear that faced by the people in the United State. In communist countries it is usual to see people walk alone at night in Park or in the street. In the communist era, the police was given so much power to control the population. Therefore, the government have so much power to regulate the use of weapons, to monitor the movement of people, imprison people that suspected to crime. It can be said that in communist countries, the social and public order become a

7 Kenneth Janda, Jeffrey M. Berry, and Jerry Goldman, The Challenge of Democracy (Massachusetts: Cengage Learning, 2013), 12-13.

8 Janda, Berry, and Goldman, 14-16. 
prioritised by the government. But after communist state collapse, the crime rate has increased in post communist countries. Even in Russia the polling that has been conducted and asked people, are they feel more safe from crime? $93 \%$ of responded answered that they do not feel safe from crime, while $7 \%$ of responded said they feel safe. ${ }^{?}$

Another example when the military in the United state tried to reduce the spread of HIV/AIDS in the military. The military took the policy that it requires that all people who wants to register in military should take a text that are they having AIDS or not. This policy strongly criticised by the communities and NGO's because this policy has deprived the right of individual freedom. That problems shows that society wants individual freedom and social order is ensured by government but that two things are contradicted which each others. In democratic system, the policy making is influenced by what people wants and what people think. Are the society wants more freedom or social order? ${ }^{10}$

Refers to the dilemma of government, it is interesting to find out weather in the implementation of Qanun Jinayah, the government has a strong argument when produced the policy. A survey conducted by Siregar in Aceh about the implementation of shariah laws shows that $61 \%$ of responded strongly agree and $3,7 \%$ responded agree and $6 \%$ of responded did not agree with implementation of Shariah laws in Aceh. The data shows that most of people in Aceh are more precede for social order than the individual freedom. Siregar also found that people in Aceh are ready for more serious action. Survey shows that $74,6 \%$ of respondents agree with shariah law such as hand-cutting punishment for thieves and $81,9 \%$ of respondents agree with death penalty for the murder. Even $90 \%$ of respondents agree for law that allows stoning and whipping punishment for people who having sex without married. ${ }^{11}$

9 Janda, Berry, and Goldman, 18.

10 Janda, Berry, and Goldman, 1.

11 Hasan Basri Siregar, "Lessons Learn from the Implementation of Islamic Shari'ah Criminal Law in Aceh, Indonesia", Journal Law and Religion 24, no. 24 (2009): 143 176. 


\section{Qanun Jinayah Does Not Definedas Private Spaces and Public Spaces}

According to Alyassa Abu Bakar (Former Head of the Office of Islamic Sharia in Aceh) Qanun Jinayah do not do separation explicitly. Thus, actions include referring Qanun Jinayah which is used more based on the interpretation of government and society. It is because there are no specific indicators based on the research used as the foundation of the birth of Qanun. Alyassa says, "Not much research has been done to support the implementation of Islamic Shariah in Aceh including the introduction of Qanun Jinayah." The impact of this condition is the understanding of various communities including the flexibility of the government at the district level in implementing the Qanun Jinayah itself. For example, four local regulations issued by the North Aceh district government to avoid the immorality include: First, Qanun which contains classrooms segregation between male and female, both for Junior High School and Senior High School (SMA). Second, banning hitchhiked among non-muhrim men and women. Third, banning the holding of shows such as keyboard, karaoke, which take place at cafe, offices, school, or campus as extra-curricular activities, wedding parties and other promotional or business activities. Fourth, prohibition of selling tight clothes which are not accordance with Islamic Sharia. Also interdiction of displaying sculptures which look like a human or animal. This Qanun was adopted by the House of Representatives of Kabupaten (DPRK) of North Aceh on April 20, 2015. ${ }^{12}$

The adoption of these different policies occurs due to different political and place, so people are required to follow the rules based on the laws of the region. This difference in interpretation leads an action or behaviour to be accepted somewhere but may be a violation elsewhere. Usually, this is related to the interaction of men and women, the rules of clothing (women) and public entertainment.

12 "Aceh Utara Keluarkan 4 Peraturan untuk Hindari Maksiat", Channel Muslim (May 25, 2017), https://www.chanelmuslim.com/ berita/aceh-utara-keluarkan-4-peraturanuntuk-hindari-maksiat/6349/, accesed November 11, 2017. 
An important note is that overall of local regulations do not have the logic of action in the policy-making process. Qanun Jinayah also does not have an acceptable implementation indicator. Even so, the former Head of the Office of Islamic Sharia said that the temporary or one-sided definitions by the government and society are influenced by the concept of religion and cultural values, for example like the concept of mubrim.

\section{The Concept of Muhrim, Private and Public Space According to Islamic and Western Perspectives}

The discussion of the private and public spaces in Islamic and Western perspectives has differences. Especially on the different understanding of the relationship of men and women who are engaged in the private spaces and public spaces. Aceh as mentioned in Qanun No. 6 of 2.014 concerning Jinayah Law establishes khamr (liquor), maisir (gambling), khalwat (mesum), ikhtilath (infatuation and kissing), zina (unconditional marriage), sexual abuse, rape, liwath (gay), musaqah (lesbian), qadraf (accusing people committing adultery) is a punishable offence. While western concepts define it is only sexual harassment and rape can be included in a criminal case.

What differs from the concept that non-mahram men and women are two-sided in a quiet place or a closed room and this is not permissible in the teachings of Islam, while in Western concepts men and women interactions have no strict limits, even for same-sex couples, they can also express their relationship in the public sphere. It leads to the argument of opposition toward the implementation of the Qanun Jinayah with the "equally fond" which is conveyed by Dede Oetama, an activist of Gaya Nusantara ${ }^{13}$ can not be a justification or defence to avoid Qanun Jinayah.

This argument has been submitted by the head of the Office of Sharia Islam, Munawar that the implementation of criminal law 2017).

13 "Pertama di Aceh, Pasangan Gay Dihukum 85 Kali Cambuk", BBC (May 17, 
based on Islamic law or jinayah is based on Law Number 11 Year 2006 regarding Aceh Government. One of the implementation of Islamic laws includes worship, family law, civil law, criminal law (jinayab), judiciary, education, da'wah, syiar, and defence of Islam. Although the argument used by the Aceh government is not sufficient to dismiss the opinion expressed by the Asian Deputy Director of Human Rights Watch's that the arrest and detention of the couple underscores the oppression in the discriminatory and anti-LGBT laws of jinayah. Munawar says the caning law in Aceh is different from that done in some other countries, this law is not intended to harm, it is more aimed in providing learning for Muslims in Aceh. ${ }^{14}$

Still associated with the concept of mahram, Alyassa also conveyed that the social values of Aceh society refers to Al-Qur'an and Sunnah by maintaining limits interaction between men and women, so it becomes as the focus of social society. In one verse of Q.S. al-Isra' [17]: 32, “And do not go near adultery; indeed, adultery is a cruel act. And a bad road." This also causes people or citizens feel disturbed when merging of men and women occurs in the private space and in the public space. Besides according to Alyasa, if there is a couple who was caught then it is not the first time residents find the behaviour that violates Qanun Jinayah it happened. "Ordinary already two or three times, or more than that." This reason also causes a great intervention by the citizens or the public to the private space of a person used by non-mahram couples or violations of similar Qanun Jinayah. Nevertheless, Alyassa admitted there is no data or related research that indicates the indicators of disruption of social order due to violation of this jarimah. For example, the impact of jarimah violations such as the number of abortions, neglected children, divorce, underage marriage, poverty, sexual harassment, dropping out, or even malnutrition. Actually, it 2017).

14 "Pertama di Aceh, Pasangan Gay Dihukum 85 Kali Cambuk", BBC (May 17, 
may be available in numbers and used as a justification (the logic of action) policy-making.

From the society point of view, the violation of the jarimah is considered disturbing politic and place in some aspects. Indah, the owner of a rent house justifies what Alyassa's argument, how she is disturbed by the behavior of the person who rents one of her houses. "They dress is fairly open and receive male guests, though not to stay overnight but that is quite disturbing". The tenant at Indah's house is a college student at one of the private universities in Banda Aceh. According to her if the tenant is women then there is a tendency this happens, the tenants tend to be more secure is men and the safest one is when the hire is a family. When the writers asked why he is disturbed by the male and female interactions in his rented house, Indah said that he was worried that the if tenants do inappropriate things like seclusion, and having sex, in fact they do not get married yet. So far, Indah just gives a direct rebuke, "But seemingly ineffective." Then, the writers asked whether she plans to report his tenants to the Sharia police or not, she replied, "She has no plan to do it as long as she has not been able to prove that the tenants have reached sexual intercourse." Next, when the writer asked why Indah feels that the action as a boundary point that she can receive, she said that parents tell if in one house do any sexual act outside of marriage, then the 44 surrounding houses will get problems and lost blessing of Allah, this reason also submitted by Ina as Indah young sister who objected if anyone commit immoral acts on their houses. "On this land there is even a grave of our grandparents who must be respected." Moreover, Indah also reminded that if she lets her tenants to commit immoral acts, then she worries people around the houses will think they do the same.

Indah also fears her nephews aged 4 and 8 years will think what the renters do is something right and proper. Furthermore, Indah said that before the tenant occupies the house, Indah has warned that the tenant should keep the actions and behaviors by not 
bringing non-mahram men into the house, let alone stay overnight. If the tenants still do it, then Indah will ask them to get out of his house.

As the owner of the house and has made a previous agreement, Indah can give a reprimand to the tenant. Indah said that if the immoral act is her neighbour who has its own house, she does not brave enough to admonish and prefer to report it to the head of the village. Here it is seen that the ownership of Indah to the rental house, can facilitate her to intervene against the tenant. Besides, Indah said that the reason she chooses to stay in this neighbourhood because she think the environment is quite good. Indah also admitted that the environment is undergoing changes with the behavior of tenants who sometimes violate the jarimah. Indah wants the environment is comfortable and not switch function to a place that she no longer recognises.

On behalf of the desire to keep the environment unchanged, Indah mentioned that she has dilemma, in one side, Indah wants to stop the behavior, one of the solutions is by raids, because so far the tenants always ignore the warning that has been said by Indah three times. Then, she does not want them to be grabbed by the community or arrested by sharia police. This is because Indah is still considering the area and environment where she lives that will be polluted. Besides Indah also still consider renters condition who is a college student.Indah fears of this problem will later affect their lives and their future. But Indah feels uncomfortable because the tenants bring a non-mahram male into his home, this makes Indah suspicious to the tenants, that they may commit jarimah violation. "If only chatting why do not talk on the terrace or outside why should be in the house." According to Indah the tenant's behavior has made her and her neighbors restless and this disturbs the social order in the neighborhood where she lives. 


\section{Citizen Report, Citizen's Presence, and Wilyatul Hisbah in Private Space}

According to Alyassa and Marzuki, what is conveyed by Indah is a general picture that causes people to decide to enter someone's private space that the allege jarimah violation happened there. In his observations, people feel the same confusion as what is experienced by Indah, between wanting orderliness and comfortable area but at the same time worrying that it will lead to be intervention into the private sphere which can affect for the environment and the perpetrator.

With regard to the presence of the WH in a person's private space, actually, this is not allowed. Sharia police are only allowed to conduct investigations in accordance with the procedure of inquiry, they also only can enter the private space of a person with a search warrant. However, it often happens, society have already done raids or arrests, then the officers came, as happened in the raid against same-sex couples in March 2017. Marzuki also confirmed that the community conducts the raid because it has been observed first. This is reinforced by Alyassa's statement that almost all incidents of hand-picking in private areas or raids by the public, the choice to enter the private territory is caused by the anger of the citizens. Communities have repeatedly warned them not to commit such misconduct or any kind of jarimah violence but they often do not listen to the citizens' warnings. As a result, people around neighbourhood take action to do raid that ultimately force citizens and officers into the private territory of them.

There is something contrary to the implementation of Islamic law through Qanun Jinayah and Islam itself. Where Islam very appreciates someone's private space. For example it is not allowed to enter someone's private space without getting permission. When going to someone's house you have to knock on the door first and say hello, when you have knocked and said three times, if you still 
get no reply or answer, then you must leave the house. So there is little confusion in the application of Qanun Jinayah, whereby citizens and WH enter private space because of efforts to uphold the Qanun itself.

Referring to the value of Islam in maintaining private space and the rampant "raids" conducted by both citizens and WH, Alyassa replied that there is a different context between the time of the Prophet with the current. The quantity as well as the effects caused by jarimah violence is much different. "In the time of Muhammad the case involving khalwat very little was due to the conditions of life of society is very good and awake, ... even people who get drunk are also rarely found." The condition of humanity and faith and morals of the ummah at that time was maintained according to Alyassa which caused the state's "intervention" to social problems such as that done by the Government of Aceh is not currently done. Alyassa conveyed even during the time of the Prophet, if any child was born of an unmarried relationship, the child would be contested for upbringing, in contrast to the present, where high abortion cases, including many babies are discarded.

From the above discussion, the question arises whether Qanun Jinayah has justification how does the country enter into the private space of the citizens as already explained there is no strong indicator. Here's an explanation about it.

\section{Qanun Jinayah: Justify without Justification}

There is no strong justification in the implementation of Qanun Jinayah including the problem of defining private spaces and public spaces, how far the state can enter person's private space. What did Alyassa and Marzuki say in the previous discussion that the indicators and justification of the sharia police enter the private sphere because of a debate whether a jarimah violator committed by someone in the private space is allowed? What is the indicator or justification that the government is entitled to enter the public's private space when a person is indicated to do sharia violations in his 
or her private space? Alyassa replied that this is determined by the choice of society itself. While at the policy-making, the references from Qanun Jinayah are UUPA as derivatives of the Helsinki MoU. Although on one occasion Yusuf Kala rejected the assumption that the implementation of Qanun Jinayah is the mandate of the MoU. It is a legal product of the Aceh government through the DPRA. ${ }^{15}$

Iskandar Usman Alfarlaky Chairman of the Banda Legislature once expressed his opinion when denying allegations if the application of Qanun Jinayah and caning law violates international law. Those who oppose it are people who do not understand about Aceh. The argument given by Usman that Aceh has the authority to implement the Qanun Jinayah and no one can sue it including the international world. ${ }^{16}$ On a separate occasion, Usman again said that Aceh has its own authority in making the rules, including the implementation of Qanun Jinayah. ${ }^{17}$ The authority and privilege of Aceh, the MoU and The Local Law (UUPA) are arguments that are more often conveyed when the implementation of caning law regulated in the Qanun Jinayah gets criticism. It shows that the Aceh government does not have The Logic of Action which is capable to explain to the public in general and the international community why Aceh chooses to apply Qanun Jinayah.

The above discussion fails to explain why the state should intervene someone's private space in the implementation of Qanun Jinayah. Ideally, when a person commits a criminal act that harms others, the state can take immediate action because it is considered to disturb public order, but when the public conducts a jarimah violence of itself in the private sphere, does the state and society have the right to enter private territory and punish people? The

15 “Indonesia Setahun Qanun Jinayah", BBC (October 24, 2016), http://www.bbc. com/indonesia/indonesia/2016/10/161023_indonesia_setahun_qanun_jinayah, accessed March 1, 2018.

16 "Ketua Banleg DPRA yang Tolak Hukum Cambuk Tak Paham Aceh", Aceh Tribunnews (October 25, 2016), http://aceh.tribunnews.com /2016/10/25/ketua-banlegdpra-yang-tolak-hukuman-cambuk-tak-paham-aceh, accessed March 1, 2018.

17 “Aceh Punya Kewenangan Sendiri”, Serambi News (May 26, 2017), http://aceh. tribunnews.com/2017/05/26/aceh-punya kewenang an -sendiri, accessed March 1, 2018. 
government did not find the answer to this question. The answer is precisely found in this paper that the offender jarimah cause public unrest even though it is done in private space that resulted in the disturbance of social order refers to the values of culture and sharia is embraced in the region of Aceh. But there is no figures or data, how the restlessness toward the offender of jarimah affects the selfperpetrators themselves and the social order.

The state in this case the Islamic Sharia Service and the people of Aceh take justification to enter the private space of a person who is considered to have a sharia violation based on the perpetrator has disturbed the citizens. In the other word the violate of jarimah violates social order. But at the same time citizens and sharia police who enter the private sphere with or without permission first participate in actions that violate the privacy rules of peeping and raiding, in addition sometimes people also do beating, soak in the gut, even in the case of arrest of gay couples record videos and spread them. This kind of actions may occur because Qanun Jinayah does not have a definite definition of separating private and public spaces as well as strictly enforcing the arrest procedure. As a result the government and society have diverse interpretations and understandings that lead to the unilateral adoption of Qanun Jinayah by governments and citizens.

Raids are a common thing which is done by community and sharia police in the implementation of Qanun Jinayah. This is usually done to catch out and find evidence. What makes this interesting when government intervention of a person's private space does not have a strong justification, then likelihood of violation of the action is quite large. Referring to Alyassa's statement, the state and the apparatus often assume that the higher the number of cases caught and ended with excesses then it becomes an achievement for the government's performance. Whereas in fact when the case is still much an indication of the failure of the state in this case related to 
the implementation of Islamic law as a whole. If the case handled through Qanun Jinayah more and used as a benchmark of the success of the implementation of the Sharia, then this just shows the failure of Islamic Shariah in Aceh.

\section{Conclusion}

The conclusion of this paper: First, Qanun Jinayah does not define what is private space and public space in the application of Qanun Jinayah. There are only two exceptional conditions for the special community for the jarimah khalwat in the study, working and home with family members as evidenced by the Family Card. Beyond these two conditions, the Qanun Jinayah applies to all forms of jarimah set in the Qanun. Second, the Qanun Jinayah does not have a strong justification for the intervention of a person's private space. This leads to unclear space constraints, diverse interpretations, and opportunities for injustice to society. Third, the Qanun Jinayah does not strictly regulate the mechanism by which the state can enter a private court so that violations of privacy and human rights may occur. For example those who feel "enforce" Sharia but actually do the sharia violation at the same time. Fourth, human rights and the argument of freedom in the private space can not be justified to avoid the Qanun Jinayah. Fifth, the justification of Qanun Jinayah enters a person's private space on the basis of social unrest, social order, and culture. Sixth, there is no logic of action in the implementation of Qanun Jinayah which is always based on MoU Helsinki and UUPA not based on the real purpose of the implementation of Islamic Shariah which is supported by the foundation of study/research and urgency of the needs of the society at this time.

Acknowledgement: This paper has been presented in the Annual International Conference on Islamic studies (AICIS) in Jakarta on November 20, 2017. 


\section{REFERENCES}

al-Bukhari, Abu Abdillah bin Ismail. al-Jami' al-Musnad ash-Shabih al-Mukhtashar min Umuri Rasulillah saw. wa Sunanubu wa Ayyamubu. Lebanon: Dar Thauq an-Najah, $1422 \mathrm{H}$.

“Aceh Punya Kewenangan Sendiri”, Serambi News, May 26, 2017, http://aceh.tribunnews.com/2017/05/26/aceh-punyakewenangan-sendiri, accessed March 1, 2018.

"Aceh Utara keluarkan 4 Peraturan untuk Hindari Maksiat", Channel Muslim, May 25, 2018, https:// www.chanelmuslim.com/ berita/aceh-utara-keluarkan-4-peraturan-untuk-hindarimaksiat/6349/, accessed November 11, 2017.

Flint, Colin, Introduction to Geopolitics. Oxon: Routledge, 2006.

"Indonesia Setahun Qanun Jinayah", BBC, October 24, 2016, http:/ / www.bbc.com/ indonesia/ indonesia/2016/10/161023 indonesia_setahun_qanun_jinayah, accesed March 1, 2018.

Janda, Kenneth, Berry M. Jeffrey, and Jerry Goldman. The Challenge of Democracy. Massachusetts: Cengage Learning, 2013.

Jones, Martin, Rhys Jones, and Michael Woods. An Introduction to Political Geography: Space, Place and Politics. London: Routledge, 2004.

"Ketua Banleg DPRA yang Tolak Hukum Cambuk Tak Paham Aceh", Aceh Tribunnews, October 25, 2016, http:// aceh. tribunnews.com/2016/10/25/ketua-banleg-dpra-yangtolak-hukuman-cambuk-tak-paham-aceh, accessed March 1, 2018.

"Pemerintah Diminta Evaluasi Hukuman Cambuk di Aceh", CNN, February 5, 2017, http://www.cnnindonesia.com /nasional/20170205144456-12-191415/pemerintahdiminta-evaluasi-hukuman-cambuk-di-aceh/, accessed March 1, 2018. 
Faradilla Fadlia and Ismar Ramadani

"Pertama di Aceh, Pasangan Gay Dihukum 85 Kali Cambuk", $B B C$, May 17, 2017, http://www.bbc.com /indonesia/ indonesia-39944910, accessed March 1, 2018.

Siregar, Hasan Basri. "Lessons Learn from the Implementation of Islamic Shari'ah Criminal Law in Aceh, Indonesia", Journal Law and Religion 24, no. 24 (2009): 143-176. 